\title{
PROFESIONALISME GURU BERBASIS NILAI-NILAI RELIGIUS DAN AKHLAK MULIA
}

\author{
Mujamil Qomar \\ Institut Agama Islam Negeri (IAIN) Tulungagung
}

\begin{abstract}
Profession, professional, and professionalism are the three words that have different editors and with different emphases, but the same substance. These three words are used in the elaboration of the position of teachers PAI. All three of understanding the existence of a work performed by the expertise, so that the three important especially in performing work involving other people in an educational institution. The teacher's role is not limited to the transfer function of knowledge to students, but teachers have a wider role in the community to creating value changes.Changes in the value of the community showed the competence of teachers able to encourage their learning interactions. The teaching profession is able to provide a strong impetus values and can convey information and knowledge to the learners. It is the responsibility inherent to each educator. Educator is the predicate in charge of implementing keteladanbased learning and religious values. The aspect of responsibility. Another thing is the issue of competence. PAI teacher competence was actually the heaviest and most complex than teachers in addition to PAI. Because the material PAI includes the disciplines of theology (tawhid), the science of morals, the science of the Koran, the science of hadith, the science of fiqh, the science of the history of Islamic culture and the Arabic language. Indeed, the Arabic language is not included in the components of PAI, but the Arabic language as a tool of science is always attached to the PAI. One can not possibly master the material PAI without the ability to master the Arabic language.
\end{abstract}

Key words: teacher professionalism, values of religious, noble character

\section{Abstrak}

Profesi, profesional, dan profesionalisme merupakan tiga kata yang memiliki redaksi berbeda dan dengan penekanan yang berlainan, tetapi substansinya sama. Ketiga kata ini digunakan dalam penjabaran kedudukan guru PAI. Ketiganya pemahaman adanya suatu pekerjaan yang dilaksanakan berdasarkan keahlian, sehingga ketiganya penting sekali khususnya dalam melaksanakan pekerjaan yang melibatkan orang lain di suatu lembaga pendidikan. Peran guru tidak sebatas berfungsi pemindah pengetahuan kepeda siswa, namun guru mempunyai peran lebih luas di masyarakat agar menciptkan perubahan-perubahan nilai. Perubahan nilai di masyarakat menunjukkan kompetensi guru mampu mendorong adanya interaksi pembelajaran. Profesi guru mampu memberikan dorongan tata nilai yang kuat dan dapat menyampaikan informasi pengetahuan kepada peserta didik. Ini merupakan tanggung jawab yang melekat kepada setiap pendidik. Pendidik merupakan predikat yang bertugas melaksanakan pembelajaran dan keteladan yang berbasis nilai-nilai agama. Aspek tersebut menjadi tanggung jawabnya. Hal lain adalah masalah kompetensi. Kompetensi guru PAI itu sebenarnya paling berat dan paling kompleks dibanding guru selain PAI. Sebab materi PAI meliputi disiplin ilmu akidah (tauhid), ilmu akhlak, ilmu al-Qur'an, ilmu hadits, ilmu fiqh, ilmu sejarah kebudayaan Islam, dan bahasa Arab. Memang bahasa Arab tidak termasuk dalam komponen-komponen PAI, tetapi bahasa Arab sebagai ilmu alat senantiasa melekat pada PAI. Seseorang tidak mungkin menguasai materi PAI tanpa kemampuan menguasai bahasa Arab.

Kata kunci : profesionalime guru, nilai-nilai religious, akhlak mulia 


\section{Pendahuluan}

Selama ini gambaran guru senantiasa serba baik seperti guru adalah pahlawan tanpa tanda jasa. Memang guru memiliki jasa yang besar bagi pembentukan kepribadian bangsa. Namun guru juga memiliki kelemahan-kelemahan, termasuk kelemahan dalam pembelajaran. E. Mulyasa mencatat tujuh kesalahan guru pada umumnya, yaitu; (1) mengambil jalan pintas dalam pembelajaran, (2) menunggu peserta didik berperilaku negatif, (3) menggunakan destructive discipline, (4) mengabaikan perbedaan peserta didik, (5) merasa paling pandai, (6) tidak adil/diskriminatif, dan (7) memaksa hak peserta didik E. (Mulyasa, 2013: 20).

Kelemahan ini juga terdapat pada guru Pendidikan Agama Islam (PAI). Bahkan guru PAI masih juga memiliki kelemahan-kelemahan lainnya. Mukhtar menyatakan bahwa posisi guru PAI pada lingkungan sekolah saat ini masih menyisakan sejumlah persoalan yang patut menjadi perhatian serius dari kita semua. Persoalan itu, antara lain: (1) rendahnya apresiasi guru PAI sebagai akibat PAI hanya salah satu mata pelajaran yang ditawarkan dan cenderung menempatkan PAI terpisah dari mata pelajaran lainnya; (2) kurangnya sikap profesional tugas guru PAI yang ditandai dengan kurangnya kemampuan dalam menyampaikan bahan pelajaran kepada siswa, memilih metode yang digunakan, dan persiapan mengajar; dan (3) kurangnya pengakuan terhadap guru PAI (Mukhtar, tt: 87-88).

Memang belakangan ini terdapat

banyak kritikan terhadap guru PAI menyangkut kompetensinya. Kompetensi ini dianggap kurang memadai khususnya dalam menguasai materi PAI itu apalagi ilmu-ilmu alat yang menjadi prasyaratnya seperti bahasa Arab dan Ushul al-Fiqh. Kondisi ini berdampak pada proses pembelajaran PAI yang dilaksanakannya. Kemudian proses pembelajaran ini berdampak terhadap hasil-hasil yang dicapai ternyata masih jauh dari harapan masyarakat. Hasil didikan PAI belum menunjukkan perilaku yang senantiasa posistif, bahkan dalam banyak kasus hasil didikan PAI tersebut menunjukkan perilaku negatif seperti keberanian melakukan korupsi, permusuhan dengan sesama Muslim, kebohongan dan sebagainya. Keadaan ini menuntut guru PAI yang kompeten.

Secara idealis, gambaran kompetensi guru PAI itu sebenarnya paling berat dan paling kompleks. Sedikitnya seorang guru PAI sama dengan mengemban tugas tujuh orang guru umum. Sebab materi PAI meliputi disiplin ilmu akidah (tauhid), ilmu akhlak, ilmu alQur'an, ilmu hadits, ilmu fiqh, ilmu sejarah kebudayaan Islam, dan bahasa Arab. Memang bahasa Arab tidak termasuk dalam komponen-komponen PAI, tetapi bahasa Arab sebagai ilmu alat senantiasa melekat pada PAI. Seseorang tidak mungkin menguasai materi PAI tanpa kemampuan menguasai bahasa Arab. Belum lagi guru PAI seharusnya juga memahami berbagai ilmu lainnya yang terkait meskipun sepintas.

Oleh karena itu, jarang ada guru PAI yang benar-benar memiliki kompetensi sesuai dengan harapan ideal. Apalagi ketika guru PAI tidak memiliki basis pendidikan pesantren, dan hanya berlatar pendidikan SMA, SMK maupun Madrasah Aliyah sekalipun sebelum memasuki jurusan PAI tersebut. Problem ini baru menyangkut tuntutan penguasaan materi PAI. Padahal untuk menjadi guru PAI yang profesional juga harus memenuhi tuntutan-tuntutan lainnya, seperti penguasaan metode pembelajaran, penguasaan psikologi anak maupun psikologi perkembangan, sehingga dibutuhkan upaya-upaya penguatan profesionalisme secara kontinyu.

\section{Penguatan Profesionalisme Guru PAI}

Kata profesi, professional, dan profesionalisme merupakan tiga kata yang memiliki redaksi berbeda dan dengan penekanan yang berlainan, tetapi substansinya sama. Ketiga kata ini digunakan dalam penjabaran makalah ini 
secara bergantian. Ketiganya bermuara pada suatu pemahaman adanya suatu pekerjaan yang dilaksanakan berdasarkan keahlian, sehingga ketiganya penting sekali khususnya dalam melaksanakan pekerjaan yang melibatkan orang lain secara langsung seperti manajer dan guru.

Banyak perhatian orang pada profesionalisme ini. Bahkan Nabi Muhammad Saw pernah bersabda: Idza wussida al-amru ila ghairi ahlihi fantadhir al-sa'ah (apabila suatu urusan diserahkan kepada orang yang bukan ahlinya, maka tunggulah saat kehancurannya). Hadits ini menunjukkan betapa Nabi telah memberikan perhatian yang sangat besar terhadap profesionalisme karena menjadi salah satu penentu keberhasilan suatu kegiatan/pekerjaan. Sekiranya profesionalisme tidak penting niscaya Nabi tidak memberikan peringatan sekeras itu. Sebuah peringatan dengan nada seolah mengancam tersebut dengan redaksi fantadhir al-sa'ah (tunggulah saat kehancurannya). Melalui redaksi semacam ancaman ini diharapkan umat Islam mementingkan profesionalisme tersebut dalam bekerja dan beraktivitas.

Konsekuensinya menuntut kepada umat Islam bahwa segala sesuatu pekerjaan yang positif harus dilakukan/ditangani secara profesional, termasuk pekerjaan mendidik atau mengajar peserta didik.Buchari Alma dkk mengatakan bahwa kegiatan mengajar (teaching) merupakan kegiatan dari suatu pekerjaan profesional, sehingga dalam melakukan pekerjaan itu dibutuhkan landasan keilmuan dan latihan-latihan dalam proses implementasinya (Buchari Alma et al.,: 2009: 2). Mulyasa menyatakan, "Kita harus mampu menyiapkan guru profesional, karena hanya guru demikian yang akan berperan di masa mendatang." Kemampuan profesional guru dalam menciptakan pembelajaran yang berkualitas sangat menentukan keberhasilan pendidikan secara keseluruhan.Pernyataan ini mengingatkan dan menyadarkan kembali bahwa guru memiliki posisi sangat strategis dalam proses pembelajaran, sehingga guru menjadi ujungtombak pendidikan maupun pembelajaran. Ketika proses pendidikan maupun pembelajaran dilakukan oleh guru yang profesional, akan cepat mampu merealisasikan hasil yang sesuai dengan harapan bersama.

Oleh karena itu, profesionalisme merupakan suatu pekerjaan yang harus dipelajari melalui proses secara serius. Profesi ini tidak bisa hanya sekedar diberikan oleh orang lain atau diwariskan orangtua kepada anaknya. Syafruddin Nurdin menyatakan, "Status profesional hanya bisa diraih melalui perjuangan yang berat dan cukup panjang (Syafruddin Nurdin, 2002: 20)." Devaney dan Sykes mengatakan bahwa profesionalisme merupakan bentuk kebebasan yang tidak bisa diberikan, namun harus diupayakan. Guru tidak hanya diberdayakan; tugas kerjanya hanya dapat diselesaikan berdasarkan standar, norma dan kondisi profesionalyang harus mulai diraihnya (Kathleen Devaney dan Gary Sykes, 1988: 4). Alma dkk menyatakan bahwa guru merupakan kunci utama keberhasilan pendidikan. Guru merupakan sales agent dari lembaga pendidikan, sehingga perilaku dan cara mengajarnya sangat mempengaruhi citra lembaga pendidikan. Maka sumberdaya guru harus dikembangkan baik melalui pendidikan, pelatihan, maupun kegiatan lain agar kemampuan profesionalnya meningkat (Alma et al., : 2009: 123-124).

Sebenarnya guru profesional sejati harus memiliki pengetahuan dan kemampuan teknis; nilai-nilai bersama tentang profesi dan konsekuensi tanggungjawabnya; mengadakan pemeriksaan dan perenungan kembali sebagai kebiasaan; mengenali, menghormati dan memperhitungkan keanekaragaman pada semua anak, dan mementingkan profesi yang memudahkan tumbuh dan berkembang (Kay A. Norlander-Case et al., 2009: 1). Dengan pengertian lain, guru profesional itu telah memenuhi kriteria kemampuan, moralitas, 
pengawasan, kesadaran pluralis, dan upaya memproteksi pekerjaannya.

Profesi itu memiliki ciri-ciri khusus yang dapat diidentifikasi dan dikenali untuk membedakan dengan identitasidentitas lainnya. Sullivan mengatakan bahwa profesi itu merupakan pekerjaan yang memiliki tiga macam karakteristik: pelatihan pengetahuan secara khusus melalui pendidikan formal dan kerja magang, pengakuan publik terhadap otonomi komunitas praktisi dalam mengatur standar pelaksanaan profesi itu, dan komitmen menekankan pemberian layanan yang baik kepada publik (William M. Sullivan,, 1995 : 2).

Menurut Mukhtar Lutfi, sebagaimana dikutip Nurdin, ada delapan kriteria yang harus dipenuhi oleh suatu pekerjaan agar dapat disebut sebagai profesi, yaitu; (1) panggilan hidup yang sepenuh waktu; (2) pengetahuan dan kecakapan/keahlian; (3) kebakuan yang universal; (4) pengabdian; (5) kecakapan diagnostik dan kompetensi aplikatif; (6) otonomi; (7) kode etik, dan (8) klien. Kreteria ini berlaku pada semua profesi, termasuk profesi guru PAI. Di samping itu, guru PAI masih diikat oleh kreteria tertentu sesuai dengan tugasnya sebagai pendidik agama Islam yang bertugas mendidikkan dan mengajarkan PAI. Materi PAI ini memiliki karakteristik tertentu. Muhaimin menyatakan,

Pendidikan agama memiliki karakteristik tersendiri yang berbeda dengan mata pelajaran lainnya. Pendidikan Agama Islam (PAI) misalnya, memiliki karakteristik sebagai berikut: (1) PAI berusaha untuk menjaga akidah peserta didik agar tetap kokoh dalam situasi dan kondisi apapun; (2) PAI berusaha menjaga dan memelihara ajaran dan nilai-nilai yang tertuang dan terkandung dalam al-Qur'an dan Hadits serta otentisitas keduanya sebagai sumber utama ajaran Islam; (3) PAI menonjolkan kesatuan iman, ilmu dan amal dalam kehidupan keseharian; (4) PAI berusaha membentuk dan mengembangkan kesalehan individu dan sekaligus kesalehan sosial; (5) PAI menjadi landasan moral dan etika dalam pengembangan ipteks dan budaya serta aspek-aspek kehidupan lainnya; (6) substansi PAI mengandung entitas-entitas yang bersifat rasional dan supra-rasional; (7) PAI berusaha menggali, mengembangkan dan mengambil ibrah dari sejarah dan kebudayaan (peradaban) Islam, dan (8) dalam beberapa hal, PAI mengandung pemahaman dan penafsiran yang beragam, sehingga memerlukan sikap terbuka dan toleran atau semangat ukhuwah Islamiyah(Muhaimin, 2006: 102).

Karakteristik ini menuntut profesionalisme guru PAI makin kompleks lagi. Karena itu, profesionalisme guru PAI paling tidak harus memenuhi sepuluh macam kreteria, yaitu: (1) kemampuan menguasai materi PAI; (2) kemampuan menguasai rumpun ilmu alat dalam memahami materi PAI; (3) kemampuan menjelaskan materi PAI dengan menggunakan perspektif berbagai bidang keilmuan lainnya yang terkait; (4) kemampuan mendidikkan dan mengajarkan PAI kepada peserta didik dengan baik; (5) kemampuan menguasai metodologi pemikiran dan pemahaman PAI dengan baik; (6) kemampuan memanage pembelajaran PAI dengan maksimal; (7) kemampuan mengamalkan kesalehan individual dan kesalehan sosial dalam perilaku keseharian; (8) memiliki pengalaman mendalam dalam mendidik dan mengajar peserta didik; (9) memiliki komitmen memberikan layanan prima kepada peserta didik; dan (10) memiliki motivasi kerja atas dasar ibadah (pengabdian).

Pertama, adalah kemampuan menguasai materi PAI. Materi PAI ini meliputi komponen al-Qur'an, hadits, akidah, akhlak, fiqh, dan sejarah kebudayaan Islam. Masing-masing komponen ini masih meliputi berbagai bidang: al-Qur'an meliputi penguasaan ilmu-ilmu al-Qur'an (seperti sabab nuzul,qira'at al-Qur'an,i'jaz al-Qur'an, nasikh-mansukh, dan qashash al-Qur'an), tafsir, dan ta'wil; hadits meliputi sanad, matan, rawi, kaedah kesahihannya, jenisnya dari segi jumlah periwayat, dan jenisnya dari segi kualitasnya; akidah 
meliputi ilmu tauhid dan ilmu kalam; akhlak meliputi etika dan pengembangan akhlak; fiqh meliputi tarikh tasri', hikmat al-tasyri', masail al-fiqh dan perbandingan madzhab (muqaranat al-madzahib). Di samping itu, fiqh juga meliputi fiqhibadah, mu'amalah, munakahat, jinayah, dan pengembangan-pengembangan fiqh kontemporer; dan sejarah kebudayaan Islam meliputi sejarah kebudayaan Islam serba objek, sejarah kebudayaan Islam serba subjek, dan kritik-kritik terhadap konstruksi sejarah.

Kedua, adalah kemampuan menguasai rumpun ilmu alat dalam memahami materi PAI. Rumpun ilmu alat ini dimaksudkan sebagai rumpun ilmu yang menjadi prasyarat dalam mempelajari dan memahami materi PAI. Misalnya, bahasa Arab, ushul al-fiqh, qawaid al-fiqh, dan metodologi penelitian hadits. Rumpun ilmu ini mutlak harus dikuasai guru PAI profesional. Sebab tanpa penguasaan rumpun ilmu alat ini, guru PAI tidak akan menguasai maupun memahami PAI itu sendiri: tanpa penguasaan bahasa Arab (minimal nahwu dan sharaf) maka guru PAI tidak akan mampu memahami al-Qur'an, hadits, dan sebagainya; tanpa penguasaan ushul alfiqh dan qawaid al-fiqh, guru PAI tidak akan memahami proses operasional perumusan hukum sesuatu dalam fiqh; dan tanpa penguasaan metodologi penelitian hadits, guru PAI tidak akan mengetahui substansi hadits shahih maupun hadits dhaif. Ketiga, adalah kemampuan menjelaskan materi PAI dengan menggunakan perspektif berbagai bidang keilmuan lain yang terkait. Mengingat alQu'an dan hadits mencakup berbagai komponen dalam kehidupan, maka dibutuhkan bantuan ilmu-ilmu lain lintas disipliner untuk menjelaskan dan memperjelas materi PAI. Misalnya, dalam mengungkapkan rahasia debu untuk menghilangkan bekas jilatan anjing maupun untuk tayamum; rahasia hikmah kesehatan dalam gerakan-gerakan shalat; rahasia niat sebagai rukun puasa, dan rahasia kesehatan dalam puasa; rahasia pengharaman memakai emas bagi laki- laki; rahasia pengharaman daging babi; dan rahasia matahari terbit dari barat ketika hari kiamat. Di samping itu, kita juga perlu mencermati ayat-ayat al-Qur'an sebagai diidentifikasi Nasruddin Razak, yaitu: surat al-Zumar: 6 terkait jumlah lapisan kandungan ibu; al-Rahman: 7 terkait dengan gravitasi; al-Dzariat: 47, alAnbiya': 104, dan Yasin: 38 terkait pemuaian alam semesta; al-An'am: 125 terkait dengan ruang hampa di angkasa luar; al-Mu'minun: 12-14 terkait proses pertumbuhan dan kejadian manusia dalam rahim; dan al-An'am: 88 terkait dengan geologi, gerak rotasi dan revolusi planet bumi (Nasruddin Razak, 1986: 94-95).

Atas dasar ini, kita terdorong untuk menyelidiki rahasia di balik madu, dahan siwak untuk gogok gigi, daun bidara untuk memandikan mayit, perbedaan kencing bayi laki-laki dengan bayi perempuan, air susu ibu dalam waktu dua tahun, keharusan berkhitan bagi orang laki-laki, darah, darah haidh, cara penyembelihan binatang, binatang yang hidup di dua alam, bangkai laut, kandungan alkohol pada berbagai makanan dan minuman, dan lain sebagainya. Maka dibutuhkan laboratorium untuk kegiatan eksperimen demi mengetahui rahasia di balik ketentuan itu semua. Dalam mengungkap rahasia di balik ketentuan itu, kita harus melibatkan berbagai disiplin ilmu lain untuk membantunya.

Keempat, adalah kemampuan mendidikkan dan mengajarkan PAI kepada peserta didik dengan baik. Guru PAI profesional dituntut mampu mendidikkan PAI dengan maksimal sehingga berhasil membentuk kepribadian PAI pada peserta didik. Selanjutnya guru PAI itu juga dituntut mampu mengajarkan PAI secara maksimal sehingga berhasil membentuk potensi intelektual yang bersandar pada PAI. Kedua kemampuan tersebut diarahkan dalam membentuk kepribadian Muslim yang utama, kepribadian yang integral, atau kepribadian yang kaffah. Sebuah kepribadian yang mampu menjamin kualitas lahir batin pada seseorang 
sebagai hasil langsung dari proses pendidikan agama Islam.

Kelima, kemampuan menguasai metodologi pemikiran dan pemahaman PAI dengan baik. Dalam al-Qur'an maupun hadits terdapat berbagai rumpun atau jenis bahan keilmuan, seperti pengetahuan sains, pengetahuan filsafat, dan pengetahuan mistik. Guru PAI profesional harus mampu menyesuaikan objek, paradigma, metode, dan kreteria pengetahuan terkait dengan karakter masing-masing keilmuan itu. Kalau materi PAI terkait dengan sains harus menggunakan parameter sains, jika terkait filsafat harus menggunakan parameter filsafat, dan jika terkait mistikmaka harus menggunakan parameter mistik. Ahmad Tafsir menjelaskan bahwa kalau pengetahuan sains, objeknya empiris, paradigmanya sains, metodenya menggunakan metode ilmiah, sedang kreterianya rasional-empiris; kalau pengetahuan filsafat, objeknya abstrakrasional, paradigmanya rasional, metodenya menggunakan metode rasional, sedang kreterianya rasional; adapun pengetahuan mistik, objeknya abstrak-supra rasional, paradigmanya mistik, metodenya menggunakan metode latihan dan/atau percaya, sedangkan kreterianya berwujud rasa, iman, logis, dan terkadang empiris (Ahmad Tafsir, 2004: 11). Maka, ketika menerangkan ayat tentang hujan memakai parameter sains yakni rasional-empirik, keesaan Tuhan (monoteisme) memakai parameter filsafat yaitu rasional, sedang isra' mi'raj, pembakaran Nabi Ibrahim, dan potensi tongkat Nabi Musa harus menggunakan parameter mistik (rasa, iman, logis, dan terkdang empiris).

Pada bagian lain, guru PAI profesional harus mencari celah untuk menjelaskan materi PAI secara meyakinkan melalui urutan doktrin, pemikiran rasional, baru pembuktian empirik. Maksudnya suatu doktrin agama Islam kalau belum bisa dirasionalkan sebaiknya dibiarkan sementara sebagai doktrin, namun sepanjang doktrin tersebut memungkinkan dirasionalkan maka harus dijelaskan secara rasional baik rasional berdasarkan hukum alam maupun rasional berdasar argumentasi, selanjutnya jika doktrin itu memungkinkan dibuktikan secara empirik maka harus ditampilkan dengan mempertunjukkan bukti-bukti empiriknya. Dengan cara ini peserta didik menjadi terpuaskan.

Keenam, adalah kemampuan memanage pembelajaran PAI secara maksimal. Dalam masalah pembelajaran, posisi guru PAI adalah sebagai manajer. Guru PAI profesional harus mampu mengelola pembelajaran sebaik mungkin, sebagai bagian dari tanggungjawabnya. Syafaruddin menegaskan, "Jadi manajemen pembelajaran menjadi tanggungjawab guru sebagai manajer adalah berkenaan dengan pemahaman, peningkatan dan pelaksanaan dari pengelolaan program pengajaran yang dilaksanakan dalam mencapai tujuan secara efektif dan efisien (Syafaruddin, 2005: 245)." Manajemen pembelajaran ini dalam meningkatkan kualitas pembelajaran meliputi pengelolaan tempat belajar/ruang kelas, peserta didik, kegiatan pembelajaran, materi pembelajaran, sumber belajar, strategi dan evaluasi pembelajaran (Martinis Yamin, 2011: 69).

Manajemen pembelajaran ini pada gilirannya mencakup manajemen kelas. Sebagai manajer kelas, guru PAI profesional harus mampu melaksanakan manajemen kelas. Manajemen kelas ini memiliki tujuan tertentu dalam mendukung keberhasilan pembelajaran. Moh. Uzer Usman menyatakan,

Tujuan umum pengelolaan kelas ialah menyediakan dan menggunakan fasilitas kelas untuk bermacam-macam kegiatan belajar dan mengajar agar mencapai hasil yang baik. Sedangkan tujuan khususnya adalah mengembangkan kemampuan siswa dalam menggunakan alat-alat belajar, menyediakan kondisi-kondisi yang memungkinkan siswa bekerja dan belajar, serta membantu siswa untuk 
memperoleh hasil yang diharapkan (Moh. Uzer Usman, 2011: 10).

Ketujuh, adalah kemampuan mengamalkan kesalehan individual dan kesalehan sosial dalam perilaku keseharian. Guru PAI sebagai figur keteladanan dan model percontohan khususnya bagi peserta didiknya, sehingga guru PAI harus ekstra hati-hati dalam melakukan suatu tindakan baik ucapan, perbuatan maupun kelakuan yang direalisasikan di dalam keluarga, masyarakat maupun sekolah. Guru PAI profesional harus mampu memberikan contoh dalam beribadah kepada Allah Swt maupun dalam beramal sosial. Kedua contoh amalan ini merupakan ekspresi dari kesalehan individual dan kesalehan sosial. Kesalehan individual bersifat vertikal karena berhubungan dengan Allah secara langsung, sedangkan kesalehan sosial lebih bersifat horizontal karena lebih menekankan interaksi dengan sesama umat manusia maupun makhluk lainnya.

Kedelapan, adalah memiliki pengalaman mendalam dalam mendidik dan mengajar peserta didik. Pengalaman menunjukkan kematangan pada seseorang, sehingga seorang yang berpengalaman sangat berbeda jauh dibanding orang yang kurang berpengalaman. Kenyataan ini berlaku pada semua lini kehidupan dan pekerjaan. Guru yang berpengalaman dalam menghadapi kesulitan-kesulitan tertentu relatif tenang dalam menghadapi dan memecahkannya, tetapi hasilnya baik. Maka terdapat sebuah ungkapan bijak, experience is the best teacher (pengalaman adalah guru yang terbaik). Oleh karena itu, pengalaman yang mendalam dapat memperkokoh profesionalisme guru PAI, sehingga guru PAI yunior harus berusaha mendapatkan pengalaman yang banyak dari berbagai kejadian.

Kesembilan, adalah memiliki komitmen memberikan layanan prima kepada peserta didik. Guru PAI profesional harus memiliki niat tulus dalam memberikan layanan prima kepada peserta didik, agar mereka berhasil dalam mengikuti proses pembimbingan, pelatihan, dan pembiasaan yang dikondisikan oleh guru PAI itu. Guru PAI profesional harus menyadari bahwa sebagian besar tenaga dan pemikirannya harus dicurahkan pada upaya mewujudkan keberhasilan peserta didiknya, sehingga mereka selalu mengikuti keinginan yang baik dari peserta didiknya, dan berusaha memenuhi keinginannya. Selanjutnya guru PAI profesional harus melibatkan diri secara emosional dengan menyelami perasaan dan problem-problem psikologis yang dihadapi peserta didiknya serta berusaha keras memberikan solusi terbaiknya.

Kesepuluh, adalah memiliki motivasi kerja atas dasar ibadah (pengabdian). Guru PAI profesional harus menyadari bahwa motif kerjanya baik dalam membimbing, melatih, mendidik, membiasakan, dan mengajar adalah atas dasar ibadah kepada Allah sebagai pengabdian. Motivasi ibadah ini memberikan pengertian bahwa guru PAI profesional dalam melaksanakan seluruh kegiatannya itu semata-mata karena ibadah kepada Allah Swt, sehingga senantiasa berupaya mewujudkan dan menunjukkan sikap bekerja yang terbaik. Praktisnya, mereka bersemangat bekerja bukan karena diawasi oleh kepala sekolah, melainkan lebih dikarenakan panggilan jiwanya, sehingga tidak ada pamrih dalam bekerja kepada siapapun kecuali hanya mencari ridha dari Allah Swt.

Demikianlah, kreteria guru PAI profesional. Profesionalisme tidak hanya diorientasikan pada pemenuhan kebutuhan material, tetapi juga diarahkan pada orientasi pemenuhan kebutuhan spiritual manusia. Guru PAI profesional diharapkan mampu menjadi penggerak kemajuan ummat.

\section{Guru Penggerak Kemajuan Ummat}

Dalam skala panjang dan berproses, posisi guru PAI amat sangat strategis. Sebab pekerjaan guru PAI sehari-hari adalah mendidik, membimbing, membina, melatih dan mengajar peserta didik sebagai generasi 
yang akan diberikan kepercayaan untuk menjadi pemimpin di masa depan. Dengan demikian, guru PAI berusaha membentuk kepribadian peserta didik yang diproyeksikan menjadi pemimpin bangsa yang akan datang, melalui proses pendidikan, pengajaran maupun pembelajaran.

Peran guru termasuk guru PAI dalam pembelajaran itu pernah digambarkan Pullias, Young, Manan, Yelon dan Weinstein sebagaimana dikutip Mulyasa ternyata memiliki peran dan fungsi yang sangat bervariasi, yaitu guru sebagai pendidik, pengajar, pembimbing, pelatih, penasehat, pembaharu (innovator), model dan teladan, pribadi, peneliti, pendorong kreativitas, pembangkit pandangan, pekerja rutin, pemindah kemah, pembawa cerita, aktor, emansipator, evaluator, pengawet, dan sebagai kulminator (Mulyasa, 2008:37). Melalui implementasi dari peran dan fungsi sebanyak ini diharapkan terjadi proses akselerasi dalam membangun sumberdaya manusia peserta didik sehingga menjadi bekal kepemimpinan yang potensial di masa mendatang dalam memimpin bangsa.

Sebagai pemimpin bangsa kelak, peserta didik yang sekarang memperoleh didikan, bimbingan dan binaan dari guru PAI, nanti ketika secara riil menjadi pemimpin bangsa dalam skala apapun memiliki kekuatan politik (political power) dalam menggerakkan kemajuan umat. Kekuatan politik ini akan menjadi lebih tersalurkan dengan baik manakala pemimpin itu juga memiliki gagasangagasan strategis dalam memberdayakan ummat yang disebut kemauan politik (political will) maupun keinginan yang baik (good will). Ketika political power, political will dan good will terpadu dalam menggerakkan kemajuan umat, maka akan menjadi kekuatan besar dalam mewujudkan kemajuan umat tersebut.

Oleh karena itu, peran guru PAI itu sesungguhnya berlapis. Artinya, dalam menggerakkan kemajuan umat tersebut, guru PAI bisa mengambil peran langsung dan peran tidak langsung. Peran langsung merupakan peran jangka pendek dan sekarang bisa direalisasikan, sedang peran tidak langsung merupakan peran jangka panjang, yaitu peran yang dapat dibuktikan kiprahnya pada masa yang akan datang. Dalam konteks ini, peran langsung guru PAI dalam menggerakkan kemajuan peserta didik bisa direalisasikan oleh guru PAI itu sendiri. Sedangkan peran tidak langsung guru PAI dalam menggerakkan kemajuan ummat adalah melalui peserta didik yang akan dioperasionalisasikan di masa mendatang. Di sinilah letak posisi strategis guru PAI dalam menggerakkan kemajuan umat.

Posisi ini menjadi sangat berbahaya bagi pihak-pihak yang ingin melemahkan kekuatan-kekuatan suatu bangsa seperti para penjajah. Bagi mereka, proses pendidikan lebih ditakuti daripada proses pembuatan senjata yang didesain untuk melawan mereka sendiri. Sebab pendidikan menghapus kelemahan, menanamkan pengaruh, memberikan kekuatan dan membangun strategi untuk melawan musuh-musuh bangsa berupa keterbelakangan, kebodohan, kemiskinan dan penindasan. Proses pendidikan inilah yang mampu membangkitkan bangsa dari keterpurukan hingga menjadi bangsa yang memiliki sumberdaya manusia (human resources) yang kuat dan bangsa bermartabat tinggi yang disegani oleh bangsa-bangsa lainnya dalam persaingan global. Maka dapat disimpulkan bahwa penjajahan sesungguhnya mendapat perlawanan paling sengit justru ketika menghadapi proses pendidikan.

Graham, seorang penulis biografi Sayid Ahmad Khan, menulis mottonya bahwa didiklah!, didiklah!, didiklah!. Semua penyakit sosio-politik di India bisa diobati dengan cara ini. Obatilah akarnya dan pohonnya akan subur (A. Mukti Ali, 1992: 65-66). Motto ini menggambarkan bahwa pendidikan menjadi akar penyelesaian bagi penyakit sosial politik yang mewabah di India. Bila pendidikannya dibereskan, maka problem-problem lainnya akan lebih mudah dipecahkan. Jika pendidikannya baik, maka bidang kehidupan lainnya akan menjadi baik sebagai akibatnya. Maka pendidikan menjadi variabel penyebab 
bagi kemajuan bangsa maupun umat, sedang bidang kehidupan lainnya baik politik, ekonomi, hukum, budaya dan kesehatan hanya sebagai variabel akibat. Intinya, pendidikan menempati posisi terpenting dalam serangkaian upaya memajukan umat.

Urgensi pendidikan yang begitu dominan ini menempatkan guru PAI memiliki peran penting dalam memajukan umat. Guru PAI ini perlu mengkonstruksi PAI menjadi pendidikan yang memiliki fungsi sangat strategis. Untuk merealisasikan fungsi ini paradigma PAI perlu dilakukan transformasi sehingga menjadi lebih berorientasi pada kemajuan. Hujair AH. Sanaky menyatakan,

Perubahan paradigma pendidikan Islam dari paradigma lama yang berorientasi ke masa lalu (abad pertengahan) ke paradigma yang berorientasi ke masa depan, paradigma yang hanya mengawetkan kemajuan ke paradigma yang merintis kemajuan, paradigma feodal ke paradigma yang berjiwa demokratis, paradigma sentralistik ke paradigma desentralistik, proses pendidikan yang berorientasi teacher centered ke student centered. Perubahan paradigma diharapkan dapat memberikan rekonstruksi terhadap asas-asas mendasar atau arah pendidikan di dalam usaha meletakkan dasar yang paling rasional untuk mengubah praksis pendidikan dalam rangka membangun masyarakat yang demokratis, religius dan tangguh menghadapi tantangan internal maupun global menuju masyarakat madani Indonesia (Hujair AH. Sanaky, 2003: x).

Perubahan-perubahan

paradigma ini sengaja didesain dalam rangka memberikan arah pencapaian kemajuan pendidikan Islam, kemudian berfungsi memberikan kontribusi terhadap kemajuan umat. Apalagi pendidikan merupakan saluran strategis yang menghubungkan langsung dengan kemajuan umat. Karena itu, bangsa yang berhasil mencapai kemajuan senantiasa didahului oleh kemajuan pendidikannya. Tidak ada bangsa yang maju tanpa sumbangan pendidikan, tidak ada bangsa yang maju dengan pendidikan yang mengalami kemunduran. Di sinilah, guru PAI bisa memainkan peran dan fungsinya dalam mewujudkan kemajuan umat yang berbasis nilai-nilai religius dan akhlak mulia.

\section{Kemajuan Ummat Berbasis Nilai-Nilai Religius dan Akhlak Mulia}

Kemajuan Barat terlalu memiliki kecondongan pada materi, sehingga peradaban yang dihasilkannya bercorak materialistik sekali. Dalam mengembangkan peradaban, Barat tidak pernah mempertimbangkan pesan-pesan Tuhan atau nilai-nilai ketuhanan. Barat hanya terpaku pada kebutuhan manusia (antroposentris) sehingga mengakibatkan peradabannya semakin jauh dari nilai-nilai ketuhanan dan pemikir-pemikirnya menjadi atheis, seperti Karl Marx, Friedrich Engels, Auguste Comte, Friedrich Nietzsche, dan Carles Darwin. Dengan kata lain, Barat gagal membangun umat yang hidup di atas nilai-nilai religius. Padahal nilai-nilai inilah yang mempengaruhi manusia sehingga mencapai keselamatan. Nilai-nilai religius ini meliputi banyak nilai. Intinya nilai-nilai positif yang melahirkan manfaat dan keselamatan bagi umat manusia adalah merupakan nilai-nilai religius. Nilai-nilai ini seperti nilai kejujuran, amanah, kedisiplinan, ketauhidan, ibadah, dan akhlak. Menurut Mohammad Daud Ali bahwa akhlak menempati posisi yang sangat penting dalam Islam. Akhlak bersama takwa merupakan buah pohon Islam yang berakarkan akidah, bercabang dan berdaun syariah (Mohammad Daud Ali, 2002: 348). Maka sepantasnya kalau misi Rasul dapat diringkas dalam menyempurnakan akhlak sebagaimana sabdanya, buitstu liutammima makarim alakhlaq (Aku diutus ke dunia ini untuk menyempurnakan akhlak). 
Oleh karena itu, sudah saatnya kita mengubah paradigma desain interaksional PAI yang kita lakukan dengan mengadakan pembenahan agar PAI yang diajarkan kepada siswa kembali mengedepankan nilai-nilai akhlak karimah sebagai pelaku dasar yang harus dimiliki oleh siswa. Nilai-nilai ini harus ditanamkan kepada siswa melalui pembelajaran yang dioperasionalisasikan dengan keteladanan, pelatihan, dan pembiasaan dalam kehidupan sehari-hari di sekolah baik di dalam maupun di luar kelas agar nilai-nilai akhlak karimah itu terinternalisasikan secara reflektif. Ketika nilai-nilai tersebut dibiasakan dalam kehidupan sehari-hari, maka akan muncul secara reflektif tanpa melalui rekayasa sama sekali.

Selanjutnya, mengingat pentingnya penanaman akhlak tersebut pada siswa, dibutuhkan metode-metode tertentu dalam membina akhlak manusia. Mukhtar menyatakan bahwa ada lima metode pendidikan yang berpengaruh dalam menanamkan pendidikan akhlak pada siswa, yaitu: (1) pendidikan dengan keteladanan, (2) pendidikan dengan adat kebiasaan, (3) pendidikan dengan nasehat, (4) pendidikan dengan memberikan perhatian, dan (5) pendidikan dengan memberikan hukuman. Tampak di sini bahwa metode pendidikan akhlak pada siswa lebih ditekankan pada model percontohan daripada pemberian hukuman, sebab sasaran pendidikan akhlak ini pada penanaman perilaku kebaikan pada siswa tanpa dilakukan perhitungan, pertimbangan maupun rekayasa terlebih dahulu.

Adapun bentuk-bentuk pengalaman pembelajaran agama Islam yang dapat dikembangkan melalui pembelajaran PAI di sekolah adalah pengalaman ibadah, pengalaman keteladanan, pengalaman problem solving, pengalaman jiwa sosial, pengalaman kemasyarakatan, pengalaman keilmuan dan sebagainya. Melalui pengalamanpengalaman ini, PAI berusaha melahirkan siswa yang beriman, berilmu dan beramal shalih. Sebagai suatu pendidikan moral, PAI tidak menghendaki pencapaian ilmu untuk ilmu semata, tetapi harus didasari oleh semangat moral yang tinggi (akhlak yang baik). Dengan demikian, maka kerja ilmu selalu terkontrol dan terarahkan dalam melahirkan teknologi yang bermanfaat bagi kebutuhan masyarakat luas. Hal ini sangat berbeda jika ilmu hanya diorientasikan untuk ilmu semata (science for science), seseorang bisa sangat berprestasi secara keilmuan namun sangat membahayakan masyarakat. Karena itu dalam Islam, ilmu untuk ilmu itu harus diimbangi dengan ilmu untuk kebahagiaan masyarakat (science for happiness of society).

Penanaman nilai-nilai akhlak karimah pada siswa ini menjadi cikal bakal upaya internalisasi nilai-nilai akhlak yang mulia itu pada skala umat. Dalam konteks Indonesia, mayoritas populasinya beragama Islam. Jika mayoritas mereka menempuh pendidikan umum, maka mereka pernah menerima pelajaran PAI secara formal. Sementara populasi yang menempuh pendidikan pesantren dan/atau madrasah dan/atau perguruan tinggi agama Islam, mereka justru memperoleh PAI secara substantif yang muatannya justru lebih mendalam. Ini berarti dengan mendidikkan PAI pada siswa sekolah umum, apalagi ditambah siswa madrasah dan santri pesantren, maka penanaman akhlak karimah pada siswa tersebut merupakan saluran dalam memajukan umat.

Kemajuan umat berbasis nilainilai religius dan akhlak mulia tersebut memang layak diwujudkan, karena kemajuan dunia Barat yang berimbas pada kawasan-kawasan lain semakin meninggalkan nilai-nilai religius terutama nilai-nilai ketuhanan dan akhlak karimahkhususnya akhlak kepada Allah, Rasul dan orangtua. Kemajuan Barat hanya didesain dengan penekanan pada nilai-nilai kemanusiaan (humanisasi) semata sehingga hanya berorientasi pada antroposentris. Maka kemajuan peradaban umat Islam harus didesain dengan menyeimbangkan antara penekanan pada basis nilai-nilai kemanusiaan dan nilai-nilai ketuhanan, sehingga kemajuan peradaban umat Islam 
itu harus berorientasi ganda secara seimbang antara teosentris dengan antroposentris, sehingga ketika digabung menjadi teoantroposentris sebagai orientasi terpadu. Sesungguhnya upaya mewujudkan kemajuan umat berbasis nilai-nilai religius itu berarti mencerminkan orientasi ganda dan terpadu tersebut.

\section{Penutup}

Guru PAI merupakan kelompok profesi yang mempunyai tanggung jawab pembelajaran dan evaluasi terhadap kegiatas siswa di madrasah atau di sekolah. Tanggung jawab guru berdasarkan lima kompetensi yaitu, pedagogik, personal, profesional, sosial dan kepemimpinan. Kelima kompetensi membutuhkan integritas yang tinggi dalam melaksanakan tugas tersebut agar dapat memenuhi kebutuhan masyarakat. Guru PAI telah menjadi rujukan dan keteladanan di sekolah bagi lingkungan warga sekolah, namun guru PAI menjadi orang terpandang di masyarakat.

Masyarakat merupakan bagian dari stakeholder pendidikan telah menunjukkan dampak positif dari peran guru. Peran guru mempunyai tanggung jawab memberikan nilai-nilai dan budaya yang mampu mendorong perubahan peradaban mental dan kepribadian yang kuat. Oleh karena itu, sudah saatnya para guru dapat mengubah paradigma desain pembelajaran PAI agar dapat mengadakan pembenahan agar PAI yang diajarkan kepada siswa kembali mengedepankan nilai-nilai akhlak karimah sebagai pelaku dasar yang siswa. Nilai-nilai ini harus ditanamkan kepada siswa melalui pembelajaran yang dioperasionalisasikan dengan keteladanan, pelatihan, dan pembiasaan dalam kehidupan sehari-hari di sekolah baik di dalam maupun di luar kelas agar nilai-nilai akhlak karimah itu terinternalisasikan secara reflektif.

Core values pendidikan adalah terletak kepada keteladan guru dalam melaksanakan pembelajaran di kelas. Sumber tersebut menjadi pusat diseminasi masyarakat yang terdidik. Masyarakat ini menempatkan nilai, bukan materi sebagai asset yang paling berharga. Konsep dasar tersebut yang telah menjadikan guru PAI menjadi tokoh di masyarakat. Kedudukan guru itu masih tinggi di masyarakat agar kesinambungan pengembangan mutu guru senantiasa baik, maka membutuhkan pelatihan yang berjenjang dan ruang aktualisasi yang sesuai dengan bidang kompetensi bidang studinya. Ruang lingkup PAI mempunyai sasaran kompleks dapat dicermati dari karakteristik mencakup Al-Qur'an-Hadits, Sejarah Islam, Aqidah-Akhlaq dan Fiqh. Masing-masing bidang studi itu mempunyai karakteristik yang membutuhkan uraian secara mendalam agar dapat dipahami oleh guru.

\section{Daftar Pustaka}

Ali, A. Mukti. 1992. Alam Pikiran Modern Islam di India dan Pakistan, Bandung: Mizan

Tafsir, Ahmad. 2004. Filsafat Ilmu Mengurai Ontologi, Epistemologi dan Aksiologi Pengetahuan, Bandung; PT. Remaja Rosdakarya

Alma, Buchari et al., 2009. Guru Profesional Menguasai Metode dan Trampil Mengajar, Bandung: Alfabeta

Muijs, Daniel dan Reynolds,David. 2011. Effective teaching Evidence and Practice, London: sage Publication Ltd

Mulyasa, E. 2012 Menjadi Guru Profesional Menciptakan Pembelajaran Kreatif dan Menyenangkan, Bandung: PT. Remaja Rosdakarya

Sanaky, Hujair AH. 2003. Paradigma Pendidikan Islam Membangun Masyarakat Madani Indonesia, Yogyakarta; Safiria Insania Press

Ibn Isma'il al-Bukhari, Abu Abdullah Muhammad. tt. Shahih al-Bukhariy, Indonesia: Maktabah Dahlan

Devaney, Kathleen dan Sykes, Gary. 1988. Making the Case for Professionalism, dalam Aan Lieberman (ed.), Building a Professional Cultur in School, New York: Teachers College Press 
Norlander-Case, Kay A. et al., 2009. Guru Profesional Penyiapan dan Pembimbingan Praktisi Pemikir Program Pendidikan di Negara Demokrasi, Jakarta: PT. Indeks

Yamin, Martinis. 2001. Paradigma Baru Pembelajaran, Saiful Ibad (ed.), Jakarta: Gaung Persada Press

Daud Ali, Mohammad. 2002. Pendidikan Agama Islam, Jakarta: PT. Raja Grafindo Persada

Uzer Usman, Moh. 2011. Menjadi Guru Profesional, Bandung: PT. Remaja Rosdakarya

Muhaimi. , 2006. Nuansa Baru Pendidikan Islam Mengurai Benang Kusut Dunia Pendidikan, Jakarta: PT. Raja Grafindo Persada,

Mukhtar. tt. Desain Pembelajaran Pendidikan Agama Islam, ttp: Misaka Galiza

Razak, Nasruddin. tt. Dienul Islam Penafsiran Kembali Islam Sebagai Suatu Aqidah dan Way of Life, Bandung: PT. Alma'arif,

Nurdin, Syafaruddin. 2005. Manajemen Lembaga Pendidikan Islam, Jakarta: Ciputat press, 2005.

Nurdin, Syafruddin. 2002. Guru Profesional \& Implementasi Kurikulum, Jakarta: Ciputat Press

M. Sullivan, William. 1995. Work and Integrity: The Crisis and Promise of Professionalism in America, New York: HarperCollins 